\title{
Reverse Mentoring as Facilitating Factor for the Development of a Beginning Teacher's Self-Authorship Process
}

\author{
Aldona Augustiniene and Nijole Ciuciulkiene \\ Kaunas University of Technology \\ Donelaicio 73, LT-44029 Kaunas, Lithuania
}

cross'ref http://dx.doi.org/10.5755/j01.ss.81.3.5791

\begin{abstract}
The article deals with the concept of mentorship which may be enhanced with the idea of reverse mentoring, directed towards the self-authorship process of a beginning teacher. The research findings demonstrate that the mentees in reverse mentoring process have learned to confront their own prejudice about mentor experience priority and challenge senior persons' attitudes, have become open in real learning environment, developed a dialogue with their mentor and got more self-reliant in their pedagogical solutions.

Keywords: beginning teacher, mentor, teachermentor, mentee, reverse mentoring, self-authorship, teacher education.
\end{abstract}

\section{Introduction}

A mentor is usually an experienced specialist with clearly expressed professional competencies, values, attitudes such as desire to help, having confidence in oneself and other people (Andziuliene et al., 2002). A mentor will always think about transferring information, competence, and experience to beginning teachers - the mentees, so that they can build their confidence as professionals. A mentor is supposed to be able to encourage, nurture, and provide support, because he/she has already 'walked the path' of the mentee (Little, 1990). This is a traditional understanding of mentoring which, while relying on structural characteristics and the content exchanged in the relationship, is distinguished from peer mentoring (Kram and Isabella, 1985), coaching (Hall, Otazo and Hollenbeck, 1999), developers (i.e., relationships in one's developmental network (Higgins and Kram, 2001), alternative mentoring (Allen and Finkelstein, 2003), and peer coaching (Parker, Hall and Kram, 2008).

It is suggested (Hobson et al., 2009) that mentoring is an important and effective form of emotional and psychological support of the professional development of beginning teachers (Zanting et al., 1998; Carter and Francis, 2001; Zanting et al., 2001; Bullough, 2005; Johnson et al., 2005; Lindgren, 2005; Moor et al., 2005; Marable and Raimondi, 2007; Malderez et al., 2007) which plays an important role in the socialization of beginning teachers (Bullough and Draper, 2004; Wang et al., 2008).
A positive attitude towards mentoring starts to be questioned when scientists claim the failure of schoolbased mentoring (Smith and Ingersoll, 2004; Ling, 2009; Hobson and Malderez, 2013), stating that mentoring does not always bring positive outcomes, and can actually stunt beginning teachers' professional learning and growth. The failure of school-based mentoring impedes mentee's development of informed reflective practice or 'learnacy' (Claxton, 2004), creates 'learned helplessness' (Maier and Seligman, 1976), and negatively impacts mentee's emotional well-being with the emerging practice of judgementoring (Hobson and Malderez, 2013). They highlight the urge for the search of new mentoring ways because in the context of contemporary education paradigm, based on learner-centric approach, the traditional mentor and mentee relationship limits the possibilities to form mentees' self-directed learning competencies (Strazdiene, 2009).

In the context of a prevailing variety of mentoring skills (Clutterbuck, 2011) it would be reasonable to speak not only about mentor competence and the relations with a mentee, but also to analyze a relevantly new aspect of mentoring - reverse mentoring (Cotugna and Vickery, 1998; Leh, 2005; Clutterbuck, 2011), directed towards the self-authorship process (Kegan, 1994, 2005; Baxter Magolda, 1998, 2004, 2009, 2010) of a mentee the key aspect of which is the value of his/her own personal growth too.

Reverse mentoring has clear practical application in the management and business field. In this context, reverse mentoring is precisely defined as the pairing of a younger, junior employee acting as mentor to share expertise with an older, senior colleague as the mentee (Cotugna and Vickery, 1998; Leh, 2005; Meister and Willyerd, 2010; Murphy Marcinkus, 2012).

One of most relevant attempts to conceptualize reverse mentoring is Marcinkus Murphy (2012) presented reverse mentoring characteristics and model which is created while relying on investigations of mentoring, social exchange theory, high-quality connections, and work-based learning.

The evolvement of reverse mentoring pattern was stimulated by ICT mentoring. Jamissen and Phelps (2006) noted that the traditional age related mentoring roles were likely to be reversed in ICT with younger or junior technology knowledgeable persons becoming ICT mentors for senior professionals. 
Alongside with reverse mentoring concept, specific for the management and business field, educational studies define reverse mentoring as a boomerang effect. The mentor gives advice to the mentee; the mentee expresses a thought, idea, or concept and gives the mentor a new insight. Thus, mentoring is a reverse, two-way learning process (Dickinson, Jankot and Gracon, 2009). In such a way reverse mentoring in educational studies has wider understanding than 'Younger to Older' scheme and compliments the majority of the reverse mentoring research related to the developmental relationships (Olian, Carroll and Giannantonio, 1993; Higgins and Kram, 2001; Ragins and Verbos, 2007) and developmental networks (Murphy and Kram, 2010; Marcinkus Murphy, 2012). Such a developmental perspective via critical dimensions of mutuality (Ragins and Verbos, 2007; Roberts, 2007) implies an idea of reverse mentoring as a facilitating factor for the self-authorship development of a beginning teacher.

As it has already been mentioned, the beginning teachers are confronted with many issues as they begin their teaching careers, such as classroom management, individual differences, behaviour problems, dealing with parents (Mitchell, Reilly and Logue, 2009; Augustiniene and Ciuciulkiene, 2013) and judgementoring (Hobson and Malderez, 2013). According to Baxter Magolda (2004), the process of becoming self-authored involves intense selfreflection so that persons are able to articulate 'how I know' rather than 'how everyone else knows'. When the internal voice overtakes external influences, persons are moving toward self-authorship which is a part of becoming a profesional (Hodge, Baxter Magolda and Haynes, 2009).

Alongside with a clearly stated lack of the research in reverse mentoring field (Greengard, 2002; Epstein, 2011; Hall and Jaugietis, 2011; Monkeviciene and Autukeviciene, 2011; Peciuliauskiene, 2011; Marcinkus Murphy, 2012) there is no investigations made concerning reverse mentoring as facilitating factor for development of beginning teachers self-authorship. The above mentioned aspects presuppose the research question: how can reverse mentoring facilitate the self-authorship process of a beginning teacher while developing as a professional?

Thus, this paper aims at identifying reverse mentoring aspects which move the beginning teacher - the mentee towards self-authorship process while becoming a professional.

The research methods include analysis of scientific literature and content analysis of research participants' reflections.

The article consists of three parts. In the first part, while performing scientific literature analysis, there is highlighted the interrelating aspects of mentoring, reverse mentoring and self-authorship concepts. The second and third parts present research design and the findings which reveal mentoring aspects that facilitate the self-authorship process of a beginning teacher-mentee while becoming a professional teacher.

\section{Interrelation aspects of mentoring reverse mentoring and self-authorship concepts}

The concept of mentoring can be analyzed from multiple perspectives (Bozeman and Feeney, 2007), but according to Fletcher (2012), Hobson and Malderez (2013) there still is a lack of consensus on what mentoring in teacher education is, what it can or should seek to achieve, and how it differs from mentoring in other contexts. Fletcher (2012, p. 68) points out that it is important to distinguish between mentoring in education and mentoring in other contexts'.

The most common definition of mentoring implies the interpersonal exchange between the experienced specialist (mentor) and a junior colleague (protégé) 'in which the mentor provides the protégé with career functions related to career advancement and psychosocial functions related to personal development' (Kram, 1988, cit. Hu, Thomas and Lance, 2008, p. 727).

From point of view of psychology, the concept of mentoring reflects a basic principle that humans learn skills, values, and culture directly from other humans whom they respect and admire. People tend to emulate or model the behaviour they see in others, especially if that behaviour is rewarded (Bandura, 1986). Mentoring also reflects motivation: that people seek relationships that would help to engage in competence-seeking behaviour.

In career development field mentoring has been defined as a situation in which a mentor 'helps a protégé or mentee become more professionally competent' (Cotugna and Vickery, 1998, p. 1166).

From the point of view of work-based learning, mentoring can involve a relationship between senior and subordinate workers. It can also involve relationships between peers, friends, or members of professional groups (Chandler, 2010) while learning specific skills and knowledge, along with the ability to put new learning in an appropriate workplace context (Clark, 1992). Mentoring can educate employees about critical ethical issues (Rhodes, Liang and Spencer, 2009). Mentoring can also help to reduce workplace role ambiguity (Viator, 2001) and reduce employee turnover (Hall and Smith, 2009). In teacher education, according to Jamissen and Phelps (2006), mentoring has played an important part in the development of beginning teachers or teachers who want to develop their career advancement.

It is obvious that all these interpretations of the mentoring concept remain stable in their connotation, the roots of which lay in Greek mythology: Mentor was Odysseus's trusted counselor who also guided and taught Telemachus. Thus, a mentor is an experienced specialist who professionally helps beginners and practicing colleagues to develop. A mentor must have a necessary expertise and competence in order to help a young person to seek perfection in his/her profession, acquire practical competence in his/her job (Monkeviciene and Autukeviciene, 2011). The concept space of mentoring is even more enhanced if we consider mentoring related phenomena, such as coaching, 'facilitated reflective practice' (Cox, 2013, p. 2) as a part of mentoring connotation (Hobson and Malderez, 2013). 


\section{Reverse mentoring characteristics}

\begin{tabular}{|c|c|}
\hline Characteristics & Description \\
\hline Different partner status & $\begin{array}{l}\text { By definition, a reverse mentoring relationship is composed of a younger specialist in } \\
\text { the role of mentor and an older, more experienced specialist in the role of mentee } \\
\text { (Marcinkus Murphy, 2012) }\end{array}$ \\
\hline \multicolumn{2}{|c|}{$\begin{array}{l}\text { In education studies reversiveness of mentoring starts when the mentee (the younger specialist) has the possibility to } \\
\text { influence mentor's (the senior specialist) attitudes and inspire his/her self authorship. Traditional reverse mentoring } \\
\text { roles of the appointed younger specialist in the role of mentor and an older, more experienced specialist in the role of } \\
\text { mentee, are also acceptable but do not form the main practice pattern. }\end{array}$} \\
\hline $\begin{array}{l}\text { Knowledge sharing with } \\
\text { the mentee }\end{array}$ & $\begin{array}{l}\text { Knowledge sharing with the mentee focused on learning from the mentor's technical or } \\
\text { content expertise and generational perspective (Marcinkus Murphy, 2012) }\end{array}$ \\
\hline \multicolumn{2}{|c|}{$\begin{array}{l}\text { As in education studies effective reverse mentoring is based on the duality of roles and always is a two-way flow of } \\
\text { learning effect, types of knowledge that are exchanged between the participants of mentoring process are more } \\
\text { flexible. The mentor (not only appointed younger, but also senior specialist) is giving advice to the mentee, the mentee } \\
\text { expresses a thought, idea, or concept and gives the mentor a new insight which stimulates reflection and self } \\
\text { authorship process of both: mentor and mentee. }\end{array}$} \\
\hline $\begin{array}{l}\text { Professional and } \\
\text { leadership skill } \\
\text { development }\end{array}$ & Much of leadership development is personal development (Marcinkus Murphy, 2012) \\
\hline \multicolumn{2}{|c|}{$\begin{array}{l}\text { While providing professional and leadership skill development education share similar reverse mentoring patterns with } \\
\text { business and marketing: it reduces role ambiguity and increases job satisfaction for both: mentor and mentee. }\end{array}$} \\
\hline $\begin{array}{l}\text { Commitment to the } \\
\text { shared goal of support } \\
\text { and mutual learning }\end{array}$ & $\begin{array}{l}\text { Generational differences should create a positive connection for mutual support and } \\
\text { learning (Marcinkus Murphy, 2012) }\end{array}$ \\
\hline \multicolumn{2}{|c|}{$\begin{array}{l}\text { In education studies commitment to the shared goal of support and mutual learning inspire collaboration and personal } \\
\text { self authorship. }\end{array}$} \\
\hline $\begin{array}{l}\text { Mentee Outcomes } \\
\text { (In education in a mentee } \\
\text { position there may be a } \\
\text { traditional mentor who } \\
\text { demonstrates analogous } \\
\text { results like in business } \\
\text { characteristics of reverse } \\
\text { mentoring) }\end{array}$ & $\begin{array}{l}\text { The opportunity to learn the newest content knowledge or technical skills and gain } \\
\text { exposure to the perspective of new organizational entrants. } \\
\text { Development of leadership skills through an increased ability to understand and } \\
\text { communicate across generations in the workplace. } \\
\text { Fresh perspective on the network of relationships in which their job is embedded } \\
\text { (Lankau and Scandura, 2002). } \\
\text { A developed strong tie to their mentors, acquisition of the newest technologies and } \\
\text { social networking media. } \\
\text { Enhanced social capital (Kram, 1985; Marcinkus Murphy, 2012). }\end{array}$ \\
\hline $\begin{array}{l}\text { Mentor Outcomes } \\
\text { (In education in a mentor } \\
\text { position there may be a } \\
\text { traditional mentor) }\end{array}$ & $\begin{array}{l}\text { Young professionals gain organizational knowledge, work values, approaches and } \\
\text { skills to communicate effectively. } \\
\text { Young professionals develop personal learning in terms of improved interpersonal } \\
\text { skills such as self-disclosure, active listening, empathy, and feedback (Kram, 1996; } \\
\text { Lankau and Scandura, 2002), a greater understanding of the 'interdependence or } \\
\text { connectedness of one's job to others' (Lankau and Scandura, 2002, p. 780), expansion } \\
\text { of mentors' social capital in the organization (Hezlett and Gibson, 2007). }\end{array}$ \\
\hline
\end{tabular}

Mentoring is considered (Hobson et al., 2009) to be an effective form of professional and psychological support of beginning teachers (Zanting et al., 1998, Zanting et al., 2001; Bullough, 2005; Johnson et al., 2005; Lindgren, 2005; Moor et al., 2005; Marable and Raimondi, 2007; Malderez et al., 2007), including reduced feelings of isolation, increased morale, confidence and self-esteem, professional growth and job satisfaction, and improved self-reflection and problem-solving, classroom and time management skills.

Nevertheless, as it was already mentioned, because of the emerging tendencies of judgementoring and other pathologies of mentoring (Hobson and Malderez, 2013) the traditional mentor and mentee relationship has little freedom for the development of mentees' self-directed learning competencies (Strazdiene, 2009).

Reverse mentoring is a concept initially introduced by former General Electric CEO Jack Welch (Greengard, 2002) with intention to underline the value of reverse mentoring as a means of developing the knowledge and skills needed to stay current in the workplace (Brown, 2007; Perry, 2009). Reverse mentoring is characterized in the mentoring literature as an innovative way to encourage learning and facilitate cross-generational relationships. Reverse mentoring is regarded as an alternative form of mentoring, with unique characteristics and support 
functions exchanged. While implementing reverse mentoring in business and management the initial stress is laid on non traditional formation of mentoring pairs. Main responsibility is appointed to the younger specialist as he/she is in the role of mentor for his senior partner in the role of mentee.

In the content of Table 1 there are major reverse mentoring characteristics revealed with a separate comment of their interpretation in educational context.

A senior partner in a majority of cases is in a higher administrative position than his mentor. Such relationships are implemented because younger generation (mentors) have better knowledge about technology advance and its application, whereas senior experts have large experience about working place traditions, management, leadership patterns, etc. In spite of the changed mentor and mentee roles, the traditional mission of mentoring may be regarded as unchanged: no matter what position is occupied by the participants of mentoring process, the mentor (still being a younger specialist) is more experienced in a particular subject and is teaching the mentee (a senior specialist), who has less knowledge in the subject which is being mentored.

Reverse mentoring in education has not so strictly formulated roles about reverse mentor and mentee roles. Education emphasizes that effective reverse mentoring is based on the duality of roles and always is a two-way flow of learning which may be characterized as a boomerang effect. The mentor is giving advice to the mentee; the mentee expresses a thought, idea, or concept and gives the mentor a new insight which stimulates reflection and selfauthorship process of both: mentor and mentee. Freire argues that every teacher is always a student and every student always a teacher. Freire explains that 'the educator for liberation has to die as the unilateral educator of the educatees, in order to be born again as the educatoreducatee of the educatees-educators. An educator is a person who has to live in the deep significance of Easter' (Freire, 1987).

Thus, reverse mentoring in educational studies has more variations and is not so precisely orientated towards 'Younger to Older' scheme (Dickinson, Jankot and Gracon, 2009).

The above listed characteristics of reverse mentoring (Marcinkus Murphy, 2012): 'Different partner status', 'Knowledge sharing with the mentee', 'Professional and leadership skill development of mentors', 'Commitment to the shared goal of support and mutual learning', 'Mentee outcomes' and 'Mentor outcomes', demonstrate the potential possibilities of reverse mentoring for personal development.

Characteristic 'Different partner status' implies the possibility the younger participant to initiate learning ideas which are accepted by a senior participant. As it was mentioned before, in business, marketing, personal relations, the mentee's status in organization is always higher than the mentor's. In educational studies the focus is on the educational initiative coming from younger participant and accepted by a senior participant.
Characteristic 'Knowledge sharing with the mentee' is the main focus in a reverse mentoring relationship. According to Wanberg et al. (2003) there are the following types of knowledge exchanged in reverse mentoring process: declarative knowledge, procedural knowledge, strategic or tacit knowledge, knowledge organization, or cognitive strategies, skill-based learning, which improves technical or motor skills and affective based learning, which enables attitudinal or motivational changes.

Characteristic 'Professional and leadership skill development of mentors' reveal the possibility for young leaders to grow. In a reverse mentoring relationship, leadership development in the form of personal learning is particularly important for mentors (the younger specialists) because it can reduce role ambiguity and increase job satisfaction for both: mentor and mentee (Lankau and Scandura, 2002).

Characteristic 'Commitment to the shared goal of support and mutual learning' implies the unique dynamics of reverse mentoring relationship. Mentor and mentee are encouraged to share knowledge, positive meaning, and emotions in the creation of a positive connection (Spreitzer, 2006). Mutual support for learning is more likely to occur if participants develop a close mentoring bond - a dialogue (Ragins and Verbos, 2007; Augustiniene and Ciuciulkiene, 2013), which highlights the commitment aspect (Dutton and Heaphy, 2003) leading reverse mentoring participants to a development of self-authorship (Kegan, 1994; Baxter Magolda, 1998).

Characteristic of 'Mentor Outcomes' reveals mentors benefits of participating in a reverse mentoring. For mentors, the primary benefit of participating in a reverse mentoring relationship is their own leadership development and the experience of managing a professional mentoring relationship. Through interactions young professionals gain organizational knowledge, such as insight into the leadership hierarchy of the organization and learning how to navigate and get work done in the organization, mentors understand differing work values and approaches and to communicate effectively.

Through the process of reverse mentoring, mentors should increase personal learning in terms of improved interpersonal skills such as self-disclosure, active listening, empathy, and feedback (Kram, 1996; Lankau and Scandura, 2002). In addition, increases in relational job learning are based on a greater understanding of the 'interdependence or connectedness of one's job to others' (Lankau and Scandura, 2002, p. 780). Finally, reverse mentoring should expand mentors' intraorganizational network thus increasing their social capital in the organization, which is the ability to gain access to the resources of others through social ties (Hezlett and Gibson, 2007).

While defining 'Mentee outcomes' (in this case a senior specialist) the primary benefit of participating in a reverse mentoring relationship is the opportunity to learn the newest content knowledge or technical skills and gain exposure to the perspective of new organizational entrants, ability to understand and communicate across generations in the workplace. A developed strong tie to their mentors 
stresses the growth of professional motivation and their personal commitment. For this reason it is once more possible to state that reverse mentoring outcomes develop premises to turn both participants to the self-authorship.

Expression of the professional motivation is also connected with the concept of self-authorship, which is central to professional and career decision making (Baxter Magolda, 2002). The concept of self-authorship, a constructivist developmental framework, was first developed by Kegan (1994), proceeded with Baxter Magolda (1998, 2004, 2008, 2009, 2010) and discussed by Ignelzi (2005), Laughlin and Creamer (2007), Pizzolato (2003, 2007) etc.

According to Kegan $(1994,2005)$ and Baxter Magolda (1998), self-authorship is the ability to reflect upon one's beliefs, also organize one's thoughts and feelings, and make up one's own mind. Self-authorship is the internal coordination of meaning making on all three dimensions: one's beliefs (epistemological), identity (intrapersonal), and social relations (interpersonal). Self-authorship is 'simultaneously the ability to construct knowledge in a contextual world, an ability to construct an internal identity separate from external influences, and an ability to engage in relationships without losing ones' identity' (Baxter Magolda, 1999, p. 12). It is a complex phenomenon that involves three dimensions: cognitive or what people believe and how they make meaning and judgments, interpersonal or how people view the opinions of others in relationship to their own judgments, and intrapersonal or identity as an internal sense of self-occupations (Baxter Magolda, 2008).

Baxter Magolda (2004) recognizes four distinct phases of self-authorship: it begins with becoming the author of one's own life and moving toward internal foundation, which does not occur until after age 30 . The first phase, following external formulas, refers to following formulas from the external world and lacking the ability to develop one's own voice. The second phase, crossroads, is instigated when there is dissatisfaction with following external formulas causing one to begin to consider one's own needs and perspective. The third phase becoming the author of one's own life results in deciding one's perspective and identity and how to manage relationships with others. The fourth phase, internal formulas, is defined as the management of external influences rather than being controlled by them. One develops interdependent relationships that take into consideration external circumstances and others' needs and also honours one's own internal foundation. Persons who were able to bring their internal voices to the foreground to coordinate external influence became self-authoring (Baxter Magolda, 2008, 2009, 2010).

The previously analyzed reverse mentoring characteristics will serve as a theoretical framework for empirical research of reverse mentoring as facilitating factor for the self-authorship process of a beginning teacher.

\section{Research methodology}

Research design. Although there has been few studies of the use of reverse mentoring in public relations (e.g. Hays and Swanson, 2011; Marcinkus Murphy, 2012), no large-scale assessment of the extent to which reverse mentoring is applied throughout the teacher profession (Augustiniene and Ciuciulkiene, 2013) with a special focus on self-authorship process.

The process of becoming self-authored involves intense self-reflection so that persons are able to articulate 'how I know' rather than 'how everyone else knows'. The latter questions imply the selection of qualitativeinterpretative research perspective which will reveal participants' subjective perception and experience (Rots and Aelterman, 2008; Dumenden, 2011) of the process when the beginning teachers' internal voices overtake external influences (Baxter Magolda, 2001, p. 119). For this reason the beginning teachers were asked to write down their reflections as a free text answering the question what educational initiative of a mentee mostly effected mentor's professional development.

The research had been focused on one member of the mentorship dyad - the mentee.

The sample was criterion/quota sampling. The cases were selected according the following criteria:

- the participants in this qualitative study should be the beginning teachers who have teaching experience at least 1 year;

- $\quad$ studying at full-time non degree teacher training program at the university;

- their educational practice training should be organized in the context of action research so that the mentees could demonstrate more professional selfreflection skills;

- the participants should be involved in teacher education mentoring process as a one to one relationship between a relatively inexperienced teacher (the mentee) and a relatively experienced one (the mentor) which aims to support the mentee's learning and development as a teacher, and their integration into and acceptance by the cultures of the school and the profession (Clutterbuck, 2004);

- mentee respondents who were asked to write down their reflections had to mention reverse mentoring aspects.

Data were collected during tutoring and mentoring interactions between the student and his tutor/mentor (who is also the researcher/author), from November 2012 to January 2013. The principles of research ethics were followed: responsibility of the researcher to inform respondents about the purpose of the study, voluntarism of the respondents involving in the research, principle of anonymity and justice by not giving questions about personal life of the respondents.

The total sample was 62 beginning teachers-mentees. All 62 mentees studying in the program were asked to write down their reflections on their pedagogical practice experience as a free text with a special attention to the answering the question 'What educational initiative of a 
mentee mostly affected mentor's professional development?' There were presented 40 reflections. During first examination of the content of teachersmentees reflections 24 reflections did not contain insights on reverse mentoring. The final amount, that was selected for final content analysis, was 16 reflections. The average age of the selected for further participation mentees is 31.9 years. Such age factor coincides with the idea of selfauthorship phases (Baxter Magolda, 2004), which are based on the internal foundation that does not occur until after age 30. The teaching experience of mentees is 4.1 years. All participants were females.

Data analysis. Qualitative analysis of content was based on the systematic step performance: 1) identifying the manifest categories, while referring to the 'characteristics of reverse mentoring (Table 1) underlining key' words that denote the characteristic of reverse mentoring; 2) dividing the content of categories into subcategories; 3) identification of intersecting elements in the category/subcategory content; 4) interpreting the content data (Miles and Huberman, 1994).

The number of categories was guided by frequency of mention by participants.

Content area of the written reflections was reviewed by both researchers independently. One of the researchers reviewed all the applicable comments and grouped those that were similar in meaning. Once comments were grouped, the resulting categories were provided a name to capture the meaning reflected in the group of comments (e.g. IT literacy). Next, a second researcher was given the names of the identified categories and recategorized each of the comments into the appropriate categories. In cases where the two researchers disagreed, reasons for classification were discussed and the researchers came to an agreement regarding how most accurately to categorize the reflection item. In some cases a new category was created in order to group reflection comments accurately that had been previously misclassified. After the comments had been categorized, the total number of categories was narrowed by collapsing together categories with similar underlying themes. Since the researchers were interested in common experiences among mentees, categories represented by a single stand-alone comment, made by one participant were deleted from further analyses. In such a way the final list of categories was completed and agreement was between the researchers reached.

\section{Research results}

Mentees who participated in the research presented 395 propositions, the content of which deals with clearly expressed mentoring skills, that in the context of reverse mentoring move the mentee towards self-authorship process while becoming a professional teacher. There were distinguished 10 skills groups (Table 2).

From the qualitative data analysis and data ranking it is evident that the beginning teachers-mentees mostly experience reverse mentoring as such competences as the 'Communication skills', 'IT literacy' and 'Self-evaluation skills'.
The tendency that 'Communication skills' is the most important for the respondents has become evident. This category was marked as the first rank. It consists of four subcategories. Participants noted 'Innovative ideas' in communication: 'I liked my mentor's disciplined way of lesson work. But I wanted our pupils to become disciplined and responsible too. So I suggested planning the lesson so, that the pupils could have a possibility to stand in our shoes and to communicate like teachers', presentation of the information relevant for the pupils: 'She [mentor] said that she would not risk talking about reality of youth subcultures, drug usage experience and similar things. But discussions must be realistic', active learning: '... mentor liked my new idea about triangle discussion among me, my pupils and mentor...', and argumentation competence: '...mentor liked my courage to present extraordinary arguments. She admitted that she would like to be as brave as me...'

The second rank was given to the category 'IT literacy' (Table 2) which consists of two subcategories: 'Teaching mentor to use IT', 'New technology implementation ways'. Participants reflected the unique dynamics of reverse mentoring relationship while mentees were encouraged to share knowledge (Spreitzer, 2006) as it is evident in subcategory 'Teaching mentor to use IT': 'I teach my mentor how to use IT material for the English classes. She says that it is me who made her use computers in the classroom.' The respondents point out sharing knowledge of 'New technology implementation ways': 'I guess that I am useful when we want to use new technologies in the classroom such as virtual blackboards and mobile phones'. Leh (2005, p. 30) argued that reversementoring has benefits in technology training and constructivist learning environments, that constructivist learning through reverse mentoring '... fits in well with characteristics of digital technology'.

The third rank was given to the category 'Selfevaluation skills' (Table 2) which combines two subcategories. The fourth rank was given to the category 'Group work skills', which consists of two subcategories. The subcategory 'Positive attitudes towards group work' shows mutual agreement development: 'It really mattered that kids were enjoying the talking. Finally mentor also admitted that fact...'. The subcategory 'Group work management skills' reflects mentors and mentees commitment to the shared goal of support: 'Mentor agreed with me that it really works when we both participate in a group work as equal partners. It is a good example for the kids'.

The category 'Reflection skills' marked with fifth rank combines two subcategories 'Formation of reflection understanding' and 'Reflection versus judgementoring'. Participants have mentioned ability to engage in relationships without losing one's' identity' (Baxter Magolda, 1999, p. 12): 'Me and my mentor taught each other what is really important in reflection: it is mutual understanding'. Some participants point out possibility to evaluate mentors work as support form: 'Our traditional judge mentoring model changed into mutual reflection: I was encouraged to analyze mentor's work'. 
The manifestation of categories and their ranking

\begin{tabular}{|c|c|c|c|}
\hline Category & $\mathbf{N}$ & Rank & Subcategory \\
\hline \multirow{4}{*}{ Communication skills } & \multirow{4}{*}{123} & \multirow{4}{*}{1} & Information about innovative ideas \\
\hline & & & Presentation of the information relevant for the pupils \\
\hline & & & Active learning \\
\hline & & & Argumentation competence \\
\hline \multirow{2}{*}{ IT literacy } & \multirow{2}{*}{82} & \multirow{2}{*}{2} & Teaching mentor to use IT \\
\hline & & & New technology implementation ways \\
\hline \multirow{2}{*}{ Self-evaluation skills } & \multirow{2}{*}{41} & \multirow{2}{*}{3} & Self criticism \\
\hline & & & Objectiveness towards personal outcomes \\
\hline \multirow{2}{*}{ Group work skills } & \multirow{2}{*}{37} & \multirow{2}{*}{4} & Positive attitudes towards group work \\
\hline & & & Group work management skills \\
\hline \multirow{2}{*}{ Reflection skills } & \multirow{2}{*}{29} & \multirow{2}{*}{5} & Formation of reflection understanding \\
\hline & & & Reflection versus judgementoring \\
\hline \multirow{2}{*}{ Cooperation skills } & \multirow{2}{*}{25} & \multirow{2}{*}{6} & Implementation of cooperative methods \\
\hline & & & Cooperation development \\
\hline \multirow{2}{*}{ Collaborative work skills } & \multirow{2}{*}{18} & \multirow{2}{*}{7} & Collaboration as a method \\
\hline & & & Collaborative work as personality empowerment \\
\hline \multirow{2}{*}{ Creative work skills } & \multirow{2}{*}{16} & \multirow{2}{*}{8} & Setting of creative tasks \\
\hline & & & Introducing innovations \\
\hline \multirow{3}{*}{ Self-authorship development } & \multirow{3}{*}{13} & \multirow{3}{*}{9} & Dissatisfaction with following external formulas \\
\hline & & & Deciding one's professional identity \\
\hline & & & Management of external influences \\
\hline \multirow{2}{*}{ Critical thinking } & \multirow{2}{*}{11} & \multirow{2}{*}{10} & Teaching argumentation \\
\hline & & & Teaching to debate \\
\hline Tota & & & \\
\hline
\end{tabular}

The qualitative categories 'Cooperation skills', 'Collaborative work skills' were marked with sixth and seventh ranks. The category 'Cooperation skills' shows respondents-mentees interdependence or connectedness of one's job to others (Lankau and Scandura, 2002, p. 780) in 'Implementation of cooperative methods, for example, 'We enjoyed cooperative work and especially liked 'Station' method. We were so happy that our pupils started to cooperate with each other...' and 'Cooperation development': 'Many times we: me and my mentor, returned to the same idea, but step by step we while cooperating with pupils and finally were able to prepare our project book'.

The two subcategories 'Collaboration as a method' and 'Collaborative work as personality empowerment' connected into category 'Collaborative work skills' reflect mentors and mentees awareness of their impact on each other, understanding one another's intentions (Roberts, 2007) and commitment to the shared goal of support understood as collaborative learning activities: 'My mentor always pays attention to my opinion when we plan active learning tasks. According my recommendations we implemented collaborative learning activities, distributed roles, appointed roles and activities' and as personality empowerment: 'My mentor said, that she learned from me some professional ideas, how to arrange teaching materials. I find that the most useful experience was when I reflected and evaluated collaborative learning experience.
I talked about mentor's experience too. My mentor valued my evaluation.'

The qualitative categories 'Creative work skills', 'Self-authorship development' and 'Critical thinking' were marked with eighth, ninth and tenth ranks. The category 'Self-authorship development' consists of three subcategories coherent to the phases of self-authorship (Baxter Magolda, 2004). The subcategory 'Dissatisfaction with following external formulas' reflects mentee's crossroad moment, which is instigated when there is dissatisfaction with following external formulas causing one to begin to consider one's own needs and perspective: 'I stopped worrying about the noise during the group work and mentor's remarks about lesson structure. It really mattered that kids were enjoying the talking.' The next subcategory 'Deciding one's professional identity' shows mentee becoming the author of one's own life: '... that I am a real teacher...', it is the third phase of self-authorship (Baxter Magolda, 2009) reached in reverse mentoring process. The subcategory 'Management of external influences' indicates that some participants have developed interdependent relationships that take into consideration external circumstances and others' needs and also honours one's own internal foundation: 'Finally mentor also admitted that fact. I felt like an independent teacher...', 'I suggested letting use them as the sources of information. It was a success! Mentor called me 'mentor's teacher...' 
The category 'Critical thinking' demonstrates mentee's epistemological maturity. Kegan (1994, p. 303) argued that self-authorship is the foundation for critical thinking, noting that it requires us to 'take charge of the concepts and theories of a course or discipline, marshalling on behalf of our independently chosen topic its internal procedures for formulating and validating knowledge'.

Summing up, it is possible to state that the content of categories 'Communication skills', 'IT literacy' and 'Selfevaluation skills' which were marked with 1-3 ranks may be defined as revealing reverse mentoring characteristic 'Knowledge sharing with the mentee' (Marcinkus Murphy, 2012).

The qualitative categories 'Group work skills', 'Reflection skills', 'Cooperation skills', 'Collaborative work skills' were marked with 4-7 ranks; they represent the reverse mentoring characteristics 'Commitment to the shared goal of support and mutual learning' (Marcinkus Murphy, 2012).

Categories 'Creative work skills', 'Self-authorship development' and 'Critical thinking' were marked with 810 ranks, they can be associated with the reverse mentoring characteristic 'Mentee results' (Marcinkus Murphy, 2012).

While denoting the process of self-authorship these categories reveal mentees' acquired ability to confront their own prejudice about mentor's authority and challenge senior persons' attitudes, learn to be honest and open in real learning environment, to develop a dialogue and became more self-reliant in their pedagogical solutions.

\section{Discussion}

The purpose of this study was to identify reverse mentoring aspects, which move the beginning teacher - the mentee towards self-authorship process while becoming a professional. The review of research literature highlighted the aspects of interrelating concepts of mentoring, reverse mentoring and self-authorship which being juxtaposed to judge mentoring, inspire the development of mentee's skills, influencing the process of personal self-authorship. Reverse mentoring relationships were defined in the first part of paper by several characteristics, including 'Different partner status', 'Knowledge sharing with the mentee', 'Professional and leadership skill development of mentors', 'Commitment to the shared goal of support and mutual learning', 'Mentee outcomes' and 'Mentor outcomes', demonstrate the potential possibilities of reverse mentoring for personal development.

During the research data analysis there were distinguished 10 skills groups which could be considered as representing three characteristics of reverse mentoring. The largest amount of propositions that fall into the categories 'Communication skills', 'IT literacy' and 'Selfevaluation skills' with their subcategories may be defined as revealing reverse mentoring characteristic 'Knowledge sharing with the mentee'. The qualitative categories 'Group work skills', 'Reflection skills', 'Cooperation skills', 'Collaborative work skills' represent the reverse mentoring characteristics 'Commitment to the shared goal of support and mutual learning'. Categories 'Creative work skills' and 'Critical thinking' can be associated with the reverse mentoring characteristic 'Mentee results', which can be mostly connected with self-authorship understanding. High-quality mentoring relationship 'promotes mutual growth, learning and development within the career context' (Fletcher and Ragins, 2007, p. 374).

'Commitment to the shared goal of support and mutual learning', 'Mentee outcomes' and 'Mentor outcomes' are the reverse mentoring characteristics that have clear expression in research categories.

Self-authorship process of participants reveals all four critical dimensions of mutuality (Ragins and Verbos, 2007; Roberts, 2007): mutual benefit, influence, expectations, and understanding. Mentees - beginning teachers experienced self-authorship and reverse mentoring as a result of relationship, influence each other through learning, agree on roles and boundaries in the relationship, were aware of their impact on each other, and understand one another's intentions.

These insights support the idea that reverse mentoring in education is a two-way flow of learning which may be characterized as a boomerang effect which is highlighted by Freire (1987) who argues that every teacher is always a student and every student always a teacher.

Not all reverse mentoring characteristics displayed in scientific literature were traced in the empirical research. The position 'Different partner status' was not revealed in the research because of its formal status. According to Marcinkus Murphy (2012), the mentor is an appointed younger specialist who is teaching his senior colleague technical innovations. In educational studies there is no such practice of appointing younger colleague to teach an experienced pedagogue. Still the mentee may become an informal mentor while presenting relevant ideas and insights. The characteristic 'Professional and leadership skill development of mentors' is also more common in business context.

The authors of this research paper hope to direct the attention of school managers to reverse mentoring so that a systemic practice with a tendency to judgementoring can be implemented to help minimize professional gaps between different generations.

Findings of this study have some important implications for teacher education. They confirm the importance of adequate and sufficiently intensive supervision by the faculty at the training institutes, as well as of support provided by mentors during practical experiences in schools. Both forms of support considerably contribute to graduates' teaching commitment and this, in turn, can affect their intention to actually enter and remain in the teaching profession (Rots and Aelterman, 2008).

As research data demonstrate, in order to maintain student teachers' confidence, self-efficacy and motivation, it is necessary that teacher educators (including lecturers, tutors and mentors) also provide effective support to student teachers in order to help them 'navigate the inevitably emotionally charged process of becoming a teacher' (Malderez et al., 2007, p. 242). 
Findings of this study implicate that teacher education systems can contribute to the enhancement of graduates' teaching commitment through faculty and mentor support, which is an important condition in the process of becoming a teacher (Rots and Aelterman, 2008).

Authors agree with Rots and Aelterman (2008), Hobson et al. (2006) that these findings lend further support to calls for the effective selection, preparation and formal recognition of mentors, and for consistent development opportunities for faculty in teacher training programs.

The limitation of this research is the sample construction; thus it is impossible to state that the disclosed expression of self-authorship process in reverse mentoring is characteristic for entire population of beginning teacher in Lithuania. A second limitation was that this study focused on changes in attitude rather than behavior.

In future investigations, it is important to evaluate the effect of reverse mentoring on beginning teacher career development. Other relevant questions could follow: 'What is the effect of reverse mentoring on psychological support?', 'What is the effect of reverse mentoring on role modeling?'. Also, while supporting the attitudes of Haggard et al. (2011), Weinberg and Lankau (2011), Dobrow et al. (2012), it is important to apply a mutuality perspective and incorporate the mentor as well as mentee perspectives to the reverse mentoring research.

\section{Conclusions}

- Reverse mentoring is understood as an innovative way to encourage learning and facilitate crossgenerational relationships and may be characterized by such qualities as different partner status, knowledge sharing with the mentee, professional and leadership skill development of mentors, commitment to the shared goal of support and mutual learning, mentee outcomes and mentor outcomes, which demonstrate the potential possibilities for personal development and self-authorship.

- The content analysis of research participants' reflections has revealed the tendencies how reverse mentoring facilitates the self-authorship development of a beginning teacher:

- in the reverse mentoring process, participantsbeginning teachers with the mentor share the knowledge of communication skills, IT literacy and self-evaluation skills, express commitment to the shared goal of support and mutual learning of group work skills, reflection skills, as well as cooperation and collaborative work skills, mentee results in reverse mentoring were creative work skills, self-authorship development, critical thinking and abilities to confront beginning teachers own prejudice about mentor's authority and challenge senior persons' attitudes, learn to be honest and open in real learning environment, to develop a dialogue and became more self-reliant in their pedagogical solutions;
- the research participants-beginning teachers have not expressed spontaneously mentor outcomes as own leadership development, organizational knowledge, expansion of mentors' social capital in the organization;

- reverse mentoring can facilitate the selfauthorship process of a beginning teacher while developing as a professional creating context in which the elements of self-authorship, trusting the internal voice, building an internal foundation, and securing internal commitments, are being developed by reciprocal knowledge sharing, commitment to the shared goal of support and mutual learning, provides positive setting for self-reflection, learning partnership.

\section{References}

1. Allen, T.D., \& Finkenkelstein, L.M. (2003). Beyond mentoring: alternative sources and functions of developmental support. Career Development Quarterly, 51, (4), 346-355. http://dx.doi.org/10.1002/j.2161-0045.2003.tb00615.x

2. Andziulienè, L., Bankauskienė, N., Bersėniené, B., Čiučiulkienė, N., Kožemiakaitė, N., Markevičius, V., Simonaitienė, R., \& Stočkuvienè, N. (2002). Mentoring in Europe: a Lithuanian perspective of the APartMent project. Kaunas: Technologija.

3. Augustiniene, A., \& Ciuciulkiene, N. (2013). Reverse mentoring aspects in the self-authorship process of the teacher-mentor. ECER 2013 conference 'Creativity and Innovation in Educational Research'.

4. Baxter Magolda, M.B. (1998). Developing self-authorship in young adult life. Journal of College Student Development, 39, (2), 143-156.

5. Baxter Magolda, M.B. (2004). Learning Partnerships Model: A framework for promoting self-authorship. In M.B. Baxter Magolda, P.M. King (eds.). Learning partnerships: Theory and models of practice to educate for self-authorship, 37-62. Sterling, VA: Stylus.

6. Baxter Magolda, M.B. (2008). Three Elements of Self-Authorship Journal of College Student Development, 49, 269-284. http://dx.doi.org/10.1353/csd.0.0016

7. Baxter Magolda, M.B. (2009). Promoting self-authorship to promote liberal education. Journal of College \& Character, 10, (3), $1-6$.

8. Baxter Magolda, M.B. (2010). The interweaving of epistemological, intrapersonal, and interpersonal development in the evolution of self-authorship. Development and Assessment of Self-Authorship Sterling, VA: Stylus Publishing, 25-43.

9. Bozeman, B., \& Feeney, M.K. (2007). Toward a useful theory of mentoring: a conceptual analysis and critique. Administration and Society, $\quad 39, \quad$ (6), http://dx.doi.org/10.1177/0095399707304119

10. Brown, L.M. (2007, October). Gaining experience: The road map to internship (and entry-level) success. Public Relations Tactics. Retrieved from: http://www.prsa.org/intelligence/tactics/articles/view/1343/101/gai ning_experience_the_road_map_to_internship_and?utm_campaign $=$ PRSASearch\&utm_source=PRSAWebsite\&utm_medium $=$ SSearc h\&utm_term $=$ why $\% 20$ new $\% 20$ professionals $\% 20$ need $\% 20 \mathrm{a} \% 20 \mathrm{~m}$ entor

11. Bullough, R.V. (2005). Being and becoming a mentor: schoolbased teacher educators and teacher educator identity. Teaching and teacher education, 21, (2), 143-155. http://dx.doi.org/10.1016/j.tate.2004.12.002

12. Bullough, R.V., \& Draper, R.J. (2004). Making sense of a failed triad mentors, university supervisors, and positioning theory. Journal of Teacher Education, 55, (5), 407-420. http://dx.doi.org/10.1177/0022487104269804

13. Carter, M., \& Francis, R. (2001). Mentoring and beginning teachers' workplace learning. Asia-Pacific Journal of Teacher 
Education,

29 ,

(3),

249-262. http://dx.doi.org/10.1080/13598660120091856

14. Chandler, D.E., Hall, D.T., \& Kram, K.E. (2010). A Developmental Network \& Relational Savvy Approach to Talent Development: A Low-Cost Alternative. Organizational Dynamics, 39, (1), 48-56. http://dx.doi.org/10.1016/j.orgdyn.2009.10.001

15. Clark, C. (1992). Youth apprenticeships. CQ Researcher, 2, (39), 905-928

16. Claxton, G. (2004). Learning is learnable (and we ought to teach it). In Cassell, J. (Ed.). Ten Years On, The National Commission for Education Report, 237-250, Bristol.

17. Clutterbuck, D.C. (2004). Everyone needs a mentor: fostering talent in your organization. London: Chartered Institute of Personnel and Development.

18. Clutterbuck, D.C. (2011). Reverse mentoring. Clutterbuck Associates.

19. Cotugna, N., \& Vickery, C.E. (1998). Reverse mentoring: a twist to teaching technology. Journal of the American Dietetic Association, 98, (10), 1166-1168. http://dx.doi.org/10.1016/S00028223(98)00270-3

20. Cox, E. (2013). Coaching Understood: A Pragmatic Enquiry into the Coaching Process. London: Sage.

21. Dickinson, K., Jankot, T., \& Gracon, H. (2009). Technical ReportSun Mentoring: 1996 to 2009.

22. Dobrow, S.R., Chandler, D.E., Murphy, W.M., \& Kram, K.E (2012). A review of developmental networks incorporating a mutuality perspective. Journal of Management, 38, (1), 210-242. http://dx.doi.org/10.1177/0149206311415858

23. Dumenden, I.E. (2011). Agency as the acquisition of capital: the role of one-on-one tutoring and mentoring in changing a refugee student's educational trajectory. European Educational Research Journal, $\quad 10, \quad$ (4), 472-534 http://dx.doi.org/10.2304/eerj.2011.10.4.472

24. Dutton, J.E., \& Heaphy, E.D. (2003). The power of high quality connections. In K. Cameron, J.E. Dutton, R.E. Quinn (Eds.) Positive organizational scholarship, 263-278. San Francisco, CA: Berrett-Koehler.

25. Epstein, A.L. (2011). 4 tips for getting the most out of your mentor CBS Moneywatch.com.

26. Fletcher, J.K., \& Ragins, B.R. (2007). Stone Center relational cultural theory: A window on relational mentoring. In B.R. Ragins, K.E. Kram (Eds.), The handbook of mentoring at work: Research, theory, and practice, 373-99.

27. Fletcher, S. (2012). Editorial of the inaugural issue of the international journal of mentoring and coaching in education. International Journal of Mentoring and Coaching in Education, 1 , (1), 4-11. http://dx.doi.org/10.1108/20466851211231585

28. Freire, P. (1987). A pedagogy for liberation: dialogues on transforming education: South Hadley, MA: Bergin \& Garvey Publishers.

29. Greengard, S. (2002). Moving forward with reverse mentoring Workforce, 81, (3), 15

30. Haggard, D.L., Dougherty, T.W., Turban, D.B., \& Wilbanks, J.E (2011). Who is a mentor? A review of evolving definitions and implications for research. Journal of management, 37, (1), 280304. http://dx.doi.org/10.1177/0149206310386227

31. Hall, R., \& Jaugietis, Z. (2011). Developing peer mentoring through evaluation. Innovative Higher Education, 36, (1), 41-52. http://dx.doi.org/10.1007/s10755-010-9156-6

32. Hall, D.T., Otazo, K.L., \& Hollenbeck, G.P. (1999). Behind closed doors: what really happens in executive coaching. Organisational Dynamics, 27, (3), 39-52. http://dx.doi.org/10.1016/S00902616(99)90020-7

33. Hall, M., \& Smith, D. (2009). Mentoring and turnover intentions in public accounting firms: a research note. Accounting, Organizations and Society, 34, (6), 695-704. http://dx.doi.org/10.1016/j.aos.2008.11.003

34. Hays, B.A., \& Swanson, D.J. (2012). Public relations practitioners' use of reverse mentoring in the development of powerful professional relationships. PRism 9, (2).

35. Hezlett, S.A., \& Gibson, S.K. (2007). Linking mentoring and social capital: Implications for career and organization development. Advances in Developing Human Resources, 9, (3), 384-411. http://dx.doi.org/10.1177/1523422307304102
36. Higgins, M.C., \& Kram, K.E. (2001). Reconceptualizing mentoring at work: a developmental network perspective. Academy of Management Review, 26, (2), 264-268.

37. Hobson, A.J., Ashby, P., Malderez, A., \& Tomlinson, P.D. (2009). Mentoring beginning teachers: what we know and what we don't. Teaching and teacher education, 25, (1), 207-216. http://dx.doi.org/10.1016/j.tate.2008.09.001

38. Hobson, A.J., \& Malderez, A. (2013). Judgementoring and other threats to realizing the potential of school-based mentoring in teacher education. International Journal of Mentoring and Coaching in Education, 2, (2), 89-108. http://dx.doi.org/10.1108/IJMCE-03-2013-0019

39. Hobson, A.J., Malderez, A., Tracey, L., Giannakaki, M.S., Kerr, K., Pell, R.G., Chambers, G.N., Tomlinson, P.D., \& Roper, T. (2006). Becoming a teacher: student teachers' experiences of initial teacher training in England. Nottingham: Department for Education and Skills

40. Hodge, D.C., Baxter Magolda, M.B., \& Haynes, C.A. (2009). Engaged learning: enabling Self-Authorship and effective practice. Mosakowski Institute of Public Enterprise.

41. Ignelzi, M. (2005). Meaning-making in the learning and teaching process. In M.E. Wilson, L.E. Wolf-Wendel (Eds.), ASHE Reader on College Student Development Theory, 655-662. Boston, MA: Pearson Custom Publishing.

42. Jamissen, G., \& Phelps, R. (2006). The role of reflection and mentoring in ICT teacher professional development: dialogue and learning across the hemispheres. Teacher Development, 10, (3), 293-312. http://dx.doi.org/10.1080/13664530600921825

43. Johnson, S.M., Berg, J.H., \& Donaldson, M.L. (2005). Who stays in teaching and why: A review of the literature on teacher retention. Washington, DC: NRTA.

44. Kegan, R. (1994). In over our heads: The mental demands of modern life. Cambridge, MA: Harvard University Press.

45. Kegan, R. (2005). The hidden curriculum of youth: 'Whaddaya want from me?' In M.E. Wilson, L.E. Wolf-Wendel (Eds.), ASHEReaderon College Student Development Theorytyp, 67-80. Boston, MA: Pearson Custom Publishing.

46. Kram, K.E., \& Isabella, L.A. (1985). Mentoring alternatives: the role of peer relationships in career development. Academy of management Journal, 28, (1), 110-132. http://dx.doi.org/10.2307/256064

47. Kram, K.E. (1996). A relational approach to career development. The career is dead - Long live the career, 132-157.

48. Lankau, M.J., \& Scandura, T.A. (2002). An investigation of personal learning in mentoring relationships: content, antecedents, and consequences. Academy of Management Journal, 45, (4), 779 790. http://dx.doi.org/10.2307/3069311

49. Laughlin, A., \& Creamer, E.G. (2007). Engaging differences: Selfauthorship and the decision-making process. In P.E. Meszaros (Ed.), Self-Authorship: Advancing students' intellectual growth. New Directions for Teaching and Learning, 109, 43-51. http://dx.doi.org/10.1002/tl.264

50. Leh, A.S. (2005). Lessons learned from service learning and reverse mentoring in faculty development: A case study in technology training. Journal of Technology and Teacher Education, 13, (1), 25-41.

51. Lindgren, U. (2005). Experiences of beginning teachers in a school based mentoring program in Sweden. Educational studies, 31, (3), 251-263. http://dx.doi.org/10.1080/03055690500236290

52. Ling, L. (2009). Induction: making the leap. Research in Comparative and International Education, 4, (1), 87-95. http://dx.doi.org/10.2304/rcie.2009.4.1.87

53. Little, J.W. (1990). The mentor phenomenon. In C. Cazden (Ed.), Review of research in education, 16, 297-352. Washington, DC: American Educational Research Association. http://dx.doi.org/10.3102/0091732X016001297

54. Maier, S.F., \& Seligman, M.E. (1976). Learned helplessness: Theory and evidence. Journal of experimental psychology: general, 105, (1), 3. http://dx.doi.org/10.1037/0096-3445.105.1.3

55. Malderez, A., Hobson, A.J., Tracey, L., \& Kerr, K. (2007). Becoming a student teacher: core features of the experience. European Journal of Teacher Education, 30, (3), 225-248. http://dx.doi.org/10.1080/02619760701486068

56. Marable, M.A., \& Raimondi, S.L. (2007). Teachers' perceptions of what was most (and least) supportive during their first year of 
teaching. Mentoring \& Tutoring, 15, (1), 25-37. http://dx.doi.org/10.1080/13611260601037355

57. Marcinkus Murphy, W. (2012). Reverse mentoring at work: Fostering cross-generational learning and developing millennial leaders. Human Resource Management, 51, (4), 549-573. http://dx.doi.org/10.1002/hrm.21489

58. Meister, J.C., \& Willyerd, K. (2010). Mentoring Mill. Harvard Business Review, 8, 68-72.

59. Miles, M.B., \& Huberman, A.M. (1994). Qualitative Data Analysis (2nd edition). Thousand Oaks, CA: Sage Publications.

60. Mitchell, S.N., Reilly, R.C., \& Logue, M.E. (2009). Benefits of collaborative action research for the beginning teacher. Teaching and Teacher Education, 25, (2), 344-349. http://dx.doi.org/10.1016/j.tate.2008.06.008

61. Monkevičienè, O., \& Autukevičienè, B. (2011). Mentoriaus kompetencijų modelis: studentų praktikai vadovaujančiu ikimokyklinio ugdymo mentorių nuomonè. Pedagogika, 103, 64 73.

62. Moor, H., Halsey, K., Jones, M., Martin, K., Stott, A., Brown, C., \& Harland, J. (2005). Professional development for teachers early in their careers. Nottingham: DfES. Research brief and report No. 613.

63. Murphy, W.M., \& Kram, K.E. (2010). Understanding non-work relationships in developmental networks. Career Development $\begin{array}{llll}\text { International, } & 15 & \text { (7), } & 637-663\end{array}$ http://dx.doi.org/10.1108/13620431011094069

64. Olian, J.D., Carroll, S.J., \& Giannantonio, C.M. (1993). Mentor reactions to protégés: an experiment with managers. Journal of Vocational Behavior, 43, (3), 266-278. http://dx.doi.org/10.1006/jvbe.1993.1047

65. Parker, P., Hall, D.T., \& Kram, K.E. (2008). Peer coaching: a relational process for accelerating career learning. Academy of Management Learning and Education, 7, (4), 487-503. http://dx.doi.org/10.5465/AMLE.2008.35882189

66. Perry, L. (2009). Who's mentoring whom?: Be a mentor - you might learn something. Public Relations Tactics, (16), 11, 7 .

67. Pizzolato, J.E. (2003). Developing self-authorship: Exploring the experiences of high-risk college students. Journal of College Student Development, 44, (6), 797-812. http://dx.doi.org/10.1353/csd.2003.0074

68. Pizzolato, J.E. (Ed.). (2007). Assessing self-authorship, 109. San Francisco, CA: Jossey-Bass.

69. Ragins, B.R., \& Verbos, A.K. (2007). Positive relationships in action: relational mentoring and mentoring schemas in the workplace. Exploring positive relationships at work: Building a theoretical and research foundation, 91-116.

70. Rhodes, J., Liang, B., \& Spencer, R. (2009). First do no harm: Ethical principles for youth mentoring relationships. Professional psychology: Research and practice, 40, (5), 452. http://dx.doi.org/10.1037/a0015073

71. Roberts, L.M. (2007). From proving to becoming: How positive relationships create a context for self-discovery and selfactualization. Exploring positive relationships at work: Building a theoretical and research foundation, 29-45.

72. Rots, I., \& Aelterman, A. (2008). Two profiles of teacher education graduates: a discriminant analysis of teaching commitment. European Educational Research Journal, 7, (4), 523-534. http://dx.doi.org/10.2304/eerj.2008.7.4.523

73. Smith, T.M., \& Ingersoll, R.M. (2004). What are the effects of induction and mentoring on beginning teacher turnover? American Educational Research Journal, 41, (3), 681-714. http://dx.doi.org/10.3102/00028312041003681

74. Spreitzer, G.M. (2006). Leading to grow and growing to lead: Leadership development lessons from positive organizational studies. Organizational Dynamics, 35, 305-315. http://dx.doi.org/10.1016/j.orgdyn.2006.08.005

75. Strazdienè, G. (2009). Kolegiju studentu verslumo ugdymas taikant imitacinès verslo ịmonés modeli (Daktaro disertacija, Šiaulių universitetas, 2009)

76. Viator, R. (2001). The association of formal and informal public accounting mentoring with role stress and related job outcomes. Accounting, Organizations and Society, 26, (1), 73 http://dx.doi.org/10.1016/S0361-3682(00)00002-7

77. Wanberg, C.R., Welsh, E.T., \& Hezlett, S.A. (2003). Mentoring research: A review and dynamic process model. Research in personnel and human resources management, 22, 39-124. http://dx.doi.org/10.1016/S0742-7301(03)22002-8

78. Wang, J., Odell, S.J., \& Schwille, S.A. (2008). Effects of teacher induction on beginning teachers' teaching a critical review of the literature. Journal of teacher education, 59, (2), 132-152. http://dx.doi.org/10.1177/0022487107314002

79. Weinberg, F.J., \& Lankau, M.J. (2011). Formal mentoring programs: A mentor-centric and longitudinal analysis. Journal of Management, 37, (6), http://dx.doi.org/10.1177/0149206309349310

80. Zanting, A., Verloop, N., Vermunt, J.D., \& van Driel, J.H. (1998). Explicating practical knowledge: an extension of mentor teachers' roles. European Journal of Teacher Education, 21, (1), 11-28. http://dx.doi.org/10.1080/0261976980210104

81. Zanting, A., Verloop, N., \& Vermunt, J.D. (2001). Student Teachers' Beliefs about Mentoring and Learning to Teach during Teaching Practice. British Journal of Educational Psychology, 71, 57-80. http://dx.doi.org/10.1348/000709901158398

\section{A. Augustinienè, N. Čiučiulkienè}

Pradedančiųjų mokytojų savikūros procesą skatinantis veiksnys reversinė mentorystė

Santrauka

Savikūros gebejjimai yra būtina savybè pradedantiesiems mokytojams, kuria jie gali pasinaudoti susidurdami su sunkumais studijuodami, namuose, darbe. Tokie gebèjimai leidžia būti iniciatyviam, vadovautis savo vizijomis, būti atsakingam, kurti santykius su kitais žmonèmis (Kegan, 1994).

Remiantis šiuolaikine ugdymo paradigma, akcentuojančia studentocentrinị požiūrị, pastebima, kad tradiciniai mentoriaus ir globotinio santykiai yra kliūtis formuotis globotinio savivaldaus mokymosi kompetencijoms (Strazdienè, 2009). Be kitų mentoriaus gebejjimų ir kompetencijų, yra aktualu analizuoti santykinai naują mentorystès aspektą - reversinę mentorystę (Clutterbuck, 2011). Reversinè mentorystė atitinka šiuolaikinę ugdymo paradigmą, nes akcentuoja globotinio patirties reikšme mentoriaus tobulejimui. Tik atsižvelgdamas i globotinio patirtị, mentorius išsaugo ryši su organizacijos aplinka ir kartu su visu personalu. Abipusis ryšys padeda mentoriui pačiam tobulèti, suvokti, kokiu gebejimu poreikio jis nepastebejjo ar net nedrịso pripažinti jų neturịs (Clutterbuck, 2011). Savikūra (angl. Self-Authorship) yra asmenybès augimo procesas, kuris veda ị viso gyvenimo kūrimą (Kegan, 1994, 2005; Baxter Magolda, 2004, 2008, 2010; Pizzolato, 2003, 2007). Savikūros teorija grindžiama raidos koncepcija, akcentuojančia, kad žmonès nuolat tobulëja. Šis vystymasis apima besikeičiančius minčių, jausmų ir ryšių tarp pažintinių, savęs suvokimo ir santykiu su kitais dimensiju organizavimo būdus. Jei jaunuolis analizuos save, vertins, klaus ir klausysis kitų nuomonès apie save, visa tai padès jam geriau save pažinti, ịvertinti ir pagalvoti, užduoti sau esminius klausimus „kas aš esu?“”, „kaip aš žinau?“ ir „kaip aš noriu kurti santykius su kitais?“ (Baxter Magolda, 2010). Savikūra tyrinejjama kaip gebejjimas, kuris padeda suaugusiems žmonėms kovoti su iššūkiais gyvenime (Baxter Magolda, 2008). 21 - erius metus trukusios jaunų asmenų nuo 18 iki 39 metų studijos paremia Kegan poziciją, kad kompleksiškas kognityvinis, vidinis ir tarpasmeninis vystymasis yra būtinas suaugusiems, norint sukurti sudètingas ịsitikinimų, nuostatų sistemas, suformuoti identiteto jausmą ir kurti autentiškus, brandžius santykius su kitais žmonėmis (Baxter Magolda, 2004). Minèti aspektai suponuoja mokslinių tyrimų problemą: kaip reversinè mentorystė pradedantiesiems mokytojams gali palengvinti savarankišką profesionalo raidos procesą?

Straipsnyje pristatomo tyrimo duomenų rinkimo metodai mokslinès literatūros analizè, apklausa raštu. Duomenų apdorojimo metodas - kokybinè turinio analizè. Tyrimo imtis ekspertinè, kriterinè.

Straipsnyje išryškintos tarpusavyje prasminiais ryšiais susijusios sąvokos: mentoryste, reversinè mentorystė ir savikūra. Reversiné mentorystė yra suprantama kaip naujas būdas skatinti mokymąsi ir palengvinti kartų santykius. Reversinei mentorystei būdingos šios charakteristikos : skirtingas partnerių statusas, žinių pasidalijimas su globotiniu, mentoriu profesiniu ir vadovavimo igūdžiu tobulinimas, isipareigojimas bendram paramos tikslui ir abipusio mokymosi rezultatams. Šios charakteristikos tyrime siejamos su trimis savikūros dimensijomis: a) kognityvine, kuri padeda asmeniui atsakyti ị klausimą: „kaip aš žinau“, b) vidine-asmenine (vidinè, kur asmuo randa atsakymą 
klausimą: „kas aš esu“) ir c) tarpasmenine, kai asmuo save gerai suvokia ir žino: „kaip jis nori konstruoti (kurti) santykius su kitais“ ir geba tai atlikti (Baxter Magolda, 2010).

Tyrimų dalyvių refleksijos ir jų turinio analizè atskleidè šias tendencijas: reversinès mentorystès proceso dalyviai - ir mokytojaimentoriai, ir pradedantieji mokytojai-globotiniai patiria abipusio mokymosi naudą, jie ima dalytis žiniomis, tobulina bendravimo ịgūdžius, kompiuterinị raštingumą ir savęs vertinima, aiškiai issipareigoja bendram tikslui, t.y. remti mokymąsi vieniems iš kito, lavina grupinio darbo, refleksijos ịūdžius, taip pat bendradarbiavimo ir bendro darbo ịgūdžius, pradedantieji mokytojai-globotiniai reversinès mentorystès procese gali tobulinti savikūros gebejjimus, plètoti kritinio mąstymo gebejjimus, ịveikti stereotipinius ịsitikinimus apie švietimo organizaciją ir priimti iššūkj kritiškai vertinti vyresniujjų asmenų požiūrius, būti atviri realiai mokymosi aplinkai, plètoti dialogą ir labiau savimi pasitikèti priimant savarankiškus pedagoginius sprendimus. Tyrimo dalyviai - pradedantieji mokytojai - nepateikè spontaniškų teiginių apie dimensiją „,mentoriaus lyderystès plètra“, „organizacijos pažinimas, „mentorių socialinio kapitalo organizacijoje plètra“.

Reikšminiai žodžiai: reversinè mentorystè, mentorius; mokytojas mentorius; savikūra; mokytojų rengimas.

First received: September, 2013

Accepted for publication: October, 2013 